\title{
"Food Security" versus Cash Transfers: Comparative Analysis of Social Security Approaches in India and Brazil
}

\author{
Carter Vance \\ Institute of Political Economy, Carleton University, Ottawa, Canada \\ ${ }^{*}$ Corresponding author: E-Mail: cvanc034@gmail.com
}

Submitted: 1 October 2017 | In revised form: 6 February 2018 | Accepted: 14 March 2018 |

Published: 7 May 2018

\begin{abstract}
Two of the most discussed concepts in the world of social policy within the $21^{\text {st }}$ century have been those of food security, and related terms such as "food sovereignty". With increasing demand for food, both in amount and variety, in rapidly developing economies (most notably Brazil, India and China), along with shifts in the location of global agricultural consumption and production (for example, the diversion of some food grains into ethanol fuel production), national and sub-national governments have come under increasing pressure to develop explicit strategies for food security. These concerns are also increasingly supplemented by regional and global crisis around natural resources such as water and fertile lands, exacerbated by climate change [1].
\end{abstract}

\section{1. "Security" or "Sovereignty"?}

One of the troubles with food security as a concept, however, is that there is no universal definition for it, or the related cluster of concepts such as right-to-food and food sovereignty. Indeed, some of the largest clashes on the issue have arisen not between those supporting and opposing greater government involvement in food access on principle, but rather in the contested space of what this insurance of access should look like [2]. For instance, if "food security" is defined as solely a population having access to a set number of calories per day, what about issues of nutritional variety, cultural appropriateness of the food provided, and sustainability of the agricultural practices involved in its growing? Furthermore, if the food provided in order to create this "security" comes in the form of either food aid or other external imports, does this not undermine the long-term capacity of local communities to feed themselves and to freely determine their own relationship to the global food system? A related question is at what level the question of food security ought to be considered; in other words, can a nation overall be "food secure" (in the sense of having adequate stocks to feed its population), if some regions or localities continue to, for a variety of reasons ranging from geographic features to lack of adequate local distribution mechanisms, experience food insecurity? At the same time, are purely local approaches to the question appropriate, or are higher level public policy strategies necessary? None of these are easy conflicts to resolve, especially given both the contested, often contradictory, nature of state power and the conflicts of control over food systems between states, communities and, often multinational, business corporations.

This set of conflicts over definition and scope has led some to contest the term "food security" altogether as being outdated, and instead to push for "food sovereignty" as an alternative goal. It is usually stated by those pushing this distinction that the latter term is more holistic and focused on questions of control, both economic and cultural, over food systems, as opposed to a solely material focus of food security. Patel defines the call for food sovereignty as be- 
ing, "precisely about invoking a right to have rights over food", meaning that it calls for a reconsideration of food as a political subject [3]. For food sovereignty to be actualized under this conception, "requires direct democratic participation" [3], of producers and consumers in order to shape the character of the food system, rather than simply being instrumental parts within it. Such politics forms a sharp contrast to that pushed by bodies such as the World Trade Organization, which have often attempted to "legitimate the rhetoric of trade liberalization to advance neo-liberal food security" [4]. The WTO and other bodies have often argued in the context of regional food shortages that food security and food sovereignty are mutually conflicting goals, given the interconnected nature of global trade. In other words, the measure to protect food sovereignty in one nation will inevitably lead to problems of food security in another by restricting necessary food exports, and as such protectionist trade policies are primarily to blame for global food shortages. Such assertions have led states, particularly those in the Global South, to push back, asserting, as India's foreign minister did in 2008, that " "every country must first ensure its own food security" before considering the consequences for international markets" [4]. In this vision, food security is intimately linked with Westphalian sovereignty at the level of the nation-state, and is primarily the responsibility of the government to achieve. Some states have gone further than rhetorical pronouncements with this logic, with many having explicit policy strategies for food sovereignty and in the case of Ecuador in 2008, constitutionally enshrining food sovereignty as a right of its citizens [5]. It may also be said that such a notion posits food security as only achievable at the jurisdictional level of the state, and that a notion of global food security is either not achievable as such or not a relevant consideration to the actions taken by national governments. In other words, both the security and sovereignty of food at the level of one nation exist in a competitive, rather than dependent, dynamic with those of other nations, with a gain for one representing a potential loss for another.

At the same time, those people and organizations acting in favor of food sovereignty are also far from being in agreement on this or any other definition of the term. As Conversi has noted, the level at which "sovereignty" is situated by those seeking to create "food sovereignty" is often strikingly different from the Westphalian notion of state-based sovereignty [6]. Rather, "the subject has moved from the state to small-scale producers mobilizing, with or without the state" [6], creating a kind of "sovereignty from below" through community coalitions and actions. It is important to note that the emphasis on this form of sovereignty, "largely originated in response to the global agrarian restricting that began in the late 1980s", which posed an existential threat to traditional methods of food production and distribution, particularly in countries with a more agrarian economic base [6]. The culmination of these struggles in terms of political articulation is often noted as being the founding of the La Via Campesina international network in 1996, which coined the term "food sovereignty" and has been largely responsible for its global popularization. Under such a definition, a nation proclaiming itself to be "food sovereign" as a matter of national policy may actually be nothing of the sort, as this sovereignty may not respect democratic rights of citizens to participation as full-fledged actors in the food system. This notion of participation is sometimes linked to the "political power of agrarian citizenship to challenge capitalist relations" [7], by redefining both the rights and obligations of citizenship through food systems. As such, it is difficult to determine precisely what the role of government and the state is in such a conception of food sovereignty, given that it is often cast a villain in collusion with capitalist powers or a roadblock to more democratic forms of citizenship.

\section{The Market Solution}

Given all of these contradictions and contestations within the policy of creating food security (and/or sovereignty), it is not surprising that some have wanted to turn to the market as a kind of panacea to the problem. Under this view, which is supported by evidence from the replacement of direct food aid and food vouchers with cash-based assistance in emergency aid situations, the problem is not so much one of food security as income security [8]. In other words, by providing those without access to food with a simple cash transfer, ability to access existing food markets will be facilitated, without the need for direct government interventions to shape prices or provision of food. Lest this argument be dismissed purely as naïve "free market" economics, it should be pointed out that there have indeed been problems with traditional food aid programs, in that they are "increasingly being considered ineffective" by aid agencies, governments and aid recipients themselves [9]. This is both in the sense that such programs often involve bureaucratic systems and administrative costs that, "mean far fewer people can be beneficiaries, given limited resources" [8], and that they restrict, sometimes severely, the autonomy of the beneficiaries. Evidence from cash transfer systems adopted as aid measures in countries such as Ethiopia have shown that such cash aid is often used in ways to regenerate local food production and economic markets, such as via investments in a family farm, leading to longer-term food security in a way that direct food aid would not have. The cash transfers can, therefore, "promote social respect and individual autonomy of the poor" [9] by allowing them the ability to freely invest assets as they see fit and not treating them as simply objects of charity, but rather economic and social subjects in their own right. Social welfare can thereby be enhanced "without imposing the policing, paternalism and surveillance of the traditional welfare state" [10].

One of the most popular forms of direct cash transfer, originating in Mexico's Oportunidades program but now present across Latin America and moving into other parts of the Global South [11], is the Conditional Cash Transfer (CCT) system. Though the exact design of the program differs between the nations where it has been implemented, 
the basic function is that they "supply monetary benefits as long as recipients can demonstrate that they have met certain conditions" [12]. As CCT-benefits are typically restricted to families with children, these conditions most often include minimum attendance in school and children having vaccinations and regular medical check-ups. The reasoning behind the conditions is that such activities will help the children and their families build "human capital" through education and good health, thereby breaking a wider "cycle of poverty" within communities. CCT programs have been both praised and subject to a critique from activists and scholars. The most common criticisms have focused on the "inadequate targeting and means testing by government agencies responsible for them" [12], meaning that not all of the intended recipients are able to access the benefits and that the gendered nature of the program, as the benefits are usually deposited in the mother's bank account, may serve to reinforce female caregiver stereotypes and to off-load the work of social reproduction onto women without adequate compensation from the state [13]. Nevertheless, the programs have shown effectiveness at both, reducing particularly extreme poverty, and increasing school attendance and educational attainment rates [14]. For this reason, as well as their relatively low implementation costs, such programs have been implemented by governments of a variety of notional ideological positions, albeit with some distinctions in program design owing to them (with those implemented by more conservative political groupings tending to be more restrictive in terms of the conditionality).

Amongst Global South nations grappling with the problems of both food security and poverty relief, two of the largest are Brazil and India. Though the nations of course differ in a host of socioeconomic, cultural and geopolitical respects, they do face similar problems of sharp income inequality, displacement of rural populations into cities and increasing battles over land and agricultural ownership. At the same time, both countries have had, until recently, a long period of sustained economic growth, as well as centre-left governments (the Workers' Party in the case of Brazil, the Indian National Congress in the case of India), attempting to spread the benefits of that growth to a wider social strata. The differential approaches that the social security systems in each nation took in attempting to address the problem of food security are, therefore, instructive in understanding how these questions should be approached on a policy level. Though of course constrained in each case by differing economic and political contexts, as well as path dependencies within each country's existing social protection regime, there are lessons in their successes and failures. Moreover, an approach which would recognize the best aspects of each policy program could be instrumental in designing a food security policy which reconciles institutional and individual problem levels. As it is "not possible to study the technologies of power without an analysis of the political rationality underpinning them" [15], this paper will examine the political logics which informed both approaches, with an eye to seeing how these were played out in their concrete effects as implemented.

\section{The Indian Approach: Expanding "Food Security"}

The debate around the question of "food security" and a broader set of concerns around food access, food and land rights, foreign capital influence within the food system and so on [16], has been active in India for some time, with varying levels of public support and political influence [17]. Though the proximate cause of the Congress government introducing the National Food Security Act (NFSA, or the "food security bill") in 2013 was a 2005 ruling by the Indian Supreme Court which found that, "citizens of India do indeed have a constitutionally guaranteed right to food" [18], and set out guidelines to determine if this right was being achieved in practice, the issue was kept on the agenda by social movements determined to hold the government accountable to the Court's ruling. In addition, it should be noted that several Indian states which, for a variety of reasons, have a more progressive political stance and a more active labor movement, had been active in establishing state-level "food security" systems before the national government acted. This has been particularly noted in the case of Kerala, which maintains higher social and health status indicators despite its average level of economic output for an Indian state [19]. These observations point to the fact that, to the extent that other states or the national Indian government had not previously implemented such an approach, the condition of food insecurity, "persists because the concerns of poor people are invisible and their needs unpoliticised" [20]. This is consistent with Esping-Andersen's account of the development of the social democratic welfare state within the European context, which posited that, "the mobilization of working-class political power resources affects the distributional and institutional characteristics of welfare-state development" [21]. Though there is an open question as to if the Indian social movements which put pressure on the government could be classed as movements of the "working class" in a purely Marxist sense, they nevertheless were movements of a dispossessed class (or classes) of people, which did seek and enact changes to state policy through both electoral and other means.

In this sense, the NFSA is fundamentally a work of implementation, of both the Supreme Court ruling and the principles advanced by the movements which informed it, however partial this implementation may turn out to be. In terms of its concrete function, the Act does several things. Most notably, it expands and reforms the existing food subsidy and rationing system within India in order to cover more citizens, whilst also reducing the prices paid by them for subsidized staple foods [22]. The Act, in effect, represented an expansion of the existing Public Distribution System for basic food grains and cooking oils in India, along with a rollout of targeted food initiatives aimed at feeding particularly "vulnerable" population sub-groups (most particularly children and pregnant women). The critical change, however, 
was that the Act both converted existing food aid programs into legally-enshrined "rights", as opposed to conditional "assistance" that they were previously defined as, and expanded some programs, such as the Midday Meal Scheme in schools, to the whole of a target population regardless of income (i.e. all children now receive meals in school without a means-test). The aim of this approach was both to lessen potential for corruption or improper aid selectivity at the local level by simplifying food assistance distribution and to destigmatize receiving food aid by eliminating means-tests for some aid programs. Also uncluded in the bill was funding for a large expansion of child development service centres, which offer integrated medical, nutritional and educational initiatives, largely in rural communities [23]. In short, by placing the emphasis on in-kind benefits and services, as well as making these services universal access (with the exception of directly subsidized food grains, which nevertheless are intended to reach a majority of the population), the Indian government was taking the view that, instead of facilitating access to existing markets for low-income citizens, such as through cash aid, it should directly intervene in order to provide goods and services in areas where they were lacking. This approach could be seen as most akin to the notion of "decommodified access to food" [24], on a comparable level with other goods and services within a social democratic welfare state model.

In discussing the effects of the NFSA, it is important to note that the program has been fully implemented for only a short period of time, therefore much of the data on its effects, particularly in terms of long-term income or nutritional health, remains inconclusive [22]. With this said, the early returns from the program have shown promise in terms of improving nutritional status and school attendance amongst children, as well as alleviating extreme poverty in rural communities [23]. Of course, the NFSA was only one part of broader social reforms introduced by the Congress government, in particular the Rural Employment Guarantee program, all with intent of replacing, "the inefficient rationing systems of the past with a universal entitlement" [18]. For this reason, it is difficult to attribute gains in these areas to one particular policy, as it may be that only the particular interactions of these programs, as many are beneficiaries of more than one, would create such outcomes. Nevertheless, it does seem from the early data that NFSA has delivered some, though by no means all, of the "food security" it promised.

With that said, there have been a number of criticisms raised about the Act, both from the political Right in India, as well as the activists who initially pushed for the Act. Conservative commentators have expressed concern about the costs and fiscal sustainability of the bill, as well as its lack of targeting [25]. There have also been concerns raised about the administrative capacity of poorer state governments to properly implement the provisions of the Act, as well as the lack of controls on food quality within the Act [26]. Furthermore, some have questioned the NFSA's seemingly limited definition of "food security" as purely a matter of caloric intake and meal provisions, rather than taking into account both the environmental sustainability of the practices used to grow the additional food provisions and the potential for making the country further dependent on food imports, undermining a notion of food sovereignty in the long-run [27]. Even though the Act notionally creates a "right-based" form of food aid, by failing to grapple decisively with the question of ownership and production, rather than simply provision, it may be said to further a "sense of charity, rather than economic rights", as far as food aid is concerned [8]. Finally, insofar as the NFSA is intended to address poverty, it ignores the relational nature of at least a portion of poverty; namely, those situations where, "extreme vulnerability and the search for security allies the immediate interests of poor people to those of their exploiters" [20]. Examples of this would include rural migrant laborers in relation to their urban "recruiting agents", a common situation across India. An approach to this sort of poverty, which a system of social provision is not necessarily able to address, would require recognition that, "social policy is not just a battle over money and rights but also over principles of social stratification" [21]. Though the NSFA is ambitious in many ways, perhaps too ambitious for the existing administrative capacity in at least some parts of India, its inability to touch certain social questions, along with its adherence to a welfare state model which may diminish individual and community autonomy, means it is ultimately less effective than its initial proponents would have hoped.

\section{The Brazilian Approach: Market Access as "Food Security"}

In contrast to the approach of the Indian government, the Brazilian Bolsa Familia program, launched in 2003 by the centre-left Workers' Party (PT) government, takes a more individualistic, market-based approach to the question of both food security and social protection provision. As a part of the larger Fome Zero (Zero Hunger) program (which includes selective provision of school meals and distribution of nutritional supplements), one of the major stated goals of the Bolsa is to address child malnutrition amongst low-income families in Brazil. The program hopes to achieve this by providing cash transfers directly to families (in most cases to the female head of a household), on a conditional basis for children attending school and receiving regular medical checkups and vaccinations. In addition to immediate poverty relief through the provision of monetary resources, the program seeks to break the "cycle of poverty" by encouraging a development of "human capital" amongst low-income Brazilian through both the medical and educational conditions imposed on recipients. To the extent that its governing logic finds an echo within an earlier approach to social welfare, it is oddly from the Ordo-liberal idea of a "social market economy": that being a "notion of a market that was constantly supported by political regulations and had to be flanked by social intervention" [15]. The Indian NSFA's central notion is that markets, such as they exist, are not sufficient to pro- 
vide food security, and therefore the state must intervene to both actively set food prices and to directly provide food aid. Conversely, the Bolsa puts the emphasis on the ability of the individual or family to access the market. The market itself is not seen as the problem, except to the extent that it has priced-out some consumers at the low-end. The correction to this "market failure" is therefore to provide cash to those consumers in order to facilitate their access to the market. In other words, the Bolsa is fundamentally a demand-side intervention, whereas the provisions of the NFSA are on the supply side. To some extent, these differences of approach may reflect concrete realities, such as a lack of privatesector food providers in some rural areas of India, rather than a fundamental philosophical difference. Still, given that, as Lavinas points out, investment in "fundamental areas of social provision" (for example, health, education and public housing) has lagged economic growth in Brazil, there has seemingly been a substitution of decommodified access goods in favor of cash transfers [12]. Lavinas accuses this approach of ignoring the act, that "the more universal social protection systems are the more redistributive in their impact" [12], and that conditional programs like the Bolsa may, unwittingly or not, undermine the solidarity necessary for such systems to flourish.

An additional objection can be raised to the governing logic of the Bolsa program in terms of the conditions attached to the benefits. The advent of CCT as a preferred social policy measure has been identified by some scholars as being related to a "more productivist approach to social assistance" [14], wherein recipients must demonstrate a "return" on the "investment" the state is making by providing the assistance, removing the logic of a universal right to social protection. This "emphasis on the participants' active management of their risk through co-responsibility" [13] may initially appear to be more emancipatory than purely means-tested charity welfare, but insofar as it devolves the responsibility for social protection to the individual level, it can often reproduce the same stigmatizing features.

At the same time, with a note of caution that it is difficult to isolate its effects from those of other reforms pursued by the PT government, in particular a large increase in the minimum wage, it should be recognized that the Bolsa has been remarkably effective in achieving its stated goals. Poverty, particularly of the extreme variety more characteristic of rural areas of Brazil, has dropped, income inequality has ticked downward slightly (though it remains among the world's highest) and educational attendance rates have increased [28]. In specific terms of food consumption and nutrition, the impacts were similarly impressive; Bolsa recipient families reported that they consumed higher quality food [29], had access to a greater variety of foods [30], and had greater confidence in the ability to access food on a long-term basis [31]. In particular, instances of medical conditions related to nutritional deficiencies in children under five were significantly decreased for families receiving program benefits [32]. Though these effects can be easily overstated in some ways, thereby making CCT measures a social panacea, it does seem that, due to its relatively less bureaucratic nature and the presence of a state apparatus more able effectively implements the program. To some extent, the program's neoliberal features could be raised as an example of what Ferguson describes as "appropriating key elements of neoliberal reasoning for different ends", given that the overall picture of the program's impact has been in a direction of social redistribution [10].

\section{Conclusion: The Problem of Governing}

When considering the impacts of both the NFSA and the Bolsa Familia as policies, it is curious to note that "in early 2008, the Indian Government was considering Bolsa Familia as an alternate to its wasteful food subsidies" [8], before ultimately settling upon the institutional approach of the NFSA, expanding and reforming the subsidy network rather than getting rid of it outright. Whatever the reasoning behind that ultimate decision, it does point to the reality that, even when reaching different conclusions, governments concerned with the issues of food security do consider a variety of approaches.

The rights-based approach of the Food Security Act has a potentially more empowering standpoint in relation to its citizen-subjects. As well, it has a firm commitment to invest directly in care work provisioning as opposed to letting access to these services be dictated by the market. However, its ability to achieve these goals is constrained by the implementation capacity of the Indian state, as well as cultural and other barriers. This has ultimately meant that, though it remains problematic in terms of its governing logic of "co-responsibility" and its emphasis on facilitating market access to the exclusion of investment in core social services (namely health care and education), the Brazilian CCT-based approach has proven more successful at achieving food security gains. This speaks to the merits of the flexible nature and less complex implementation requirements of cash-aid approaches, building on observations about the preferable nature of cash to direct food supplies or vouchers in cases of famine relief [8]. At the same time, this should not be taken to say that cash-based approaches are inherently more effective in all contexts, and indeed that too much of a focus on them may both neglect those areas where existing markets, even given the ability to access them, do not adequately provide for the needs of the population. An approach which combines the basis-in-rights and universal principles of the Food Security Act with the flexibility and less bureaucratic nature of the Bolsa Familia, could more effectively address the set of concerns that, at present, both programs are not fully able to.

Within this approach, it should be recognized that "redistributive social policy (cash transfers) should not be played off against social investment" [9], and that the development of a wholly-articulated approach to food security requires interventions on both the supply and demand sides. Perhaps more importantly, insofar as "universalist social policies help resolve other obstacles to solidarity and unity" [21], and to 
the extent that more targeted policies do not, the latter may actually undermine the political basis for any kind of socially redistributive policy, even if a means-tested intervention may appear more effective initially. In order to see this, one need only look to the fact that, whilst both Brazil and India have experienced a change of government to a definitely right-wing one, the Bolsa Familia has been exposed to a much greater degree of rhetorical and political pushback, with program funding extremely likely to be cut in the near future. The NFSA, by contrast, has expanded to all the states in India under auspices of the Modi government. This is not to say that the critical question of administrative capacity has been answered, however, and there remain very real problems with the Act's implementation. Ultimately, the deficiencies in each approach point to the "absence of a socialist art of government, and the historical failure of the left to develop an autonomous governmentality comparable to liberalism" [10]. As a result of this failure, specific governments are then left to choose between previously existent governmentalities which do not fully address the issues they attempt to resolve. The development of such governmentality, distant though it may seem in the current context, may ultimately be the key to resolving the seeming tensions embodied by the Indian and Brazilian experiences.

\section{References and Notes}

[1] Hanjra MA, Qureshi ME. Global water crisis and future food security in an era of climate change. Food Policy. 2010;35(5):365-377. doi:10.1016/j.foodpol.2010.05.006.

[2] Kotwal A, Power K. Eating words: a discourse historical analysis of the public debate over India's 2013 National Food Security Act. On the Horizon. 2015;23(3):174-189. doi:10.1108/OTH-05-2015-0019.

[3] Patel R. Food sovereignty. The Journal of Peasant Studies. 2009;36(3):663-706. doi:10.1080/03066150903143079.

[4] Margulis ME. Trading out of the global food crisis? The World Trade Organization and the geopolitics of food security. Geopolitics. 2014;19(2):322-350. doi:10.1080/14650045.2014.920233.

[5] Giunta I. Food sovereignty in Ecuador: Peasant struggles and the challenge of institutionalization. Journal of Peasant Studies. 2014;41(6):1201-1224. doi:10.1080/03066150.2014.938057.

[6] Conversi D. Sovereignty in a changing world: From Westphalia to food sovereignty. Globalizations. 2016;13(4):484-498. doi:10.1080/14747731.2016.1150570.

[7] Martin SJ, Andrée P. Putting food sovereignty to work: civil society governmentalities and Canada's people's food policy project (2008-2011). Journal of Civil Society. 2017;13(4):374-391. doi:10.1080/17448689.2017.1355034.

[8] Standing G. How cash transfers promote the case for basic income. Basic Income Studies. 2008;3(1). doi:10.2202/1932-0183.1106.

[9] Leisering L. Extending social security to the excluded: are social cash transfers to the poor an appropriate way of fighting poverty in developing countries? Global Social Policy. 2009;9(2):246-272. doi:10.1177/1468018109104628.

[10] Ferguson J. The uses of neoliberalism. Antipode. 2010;41(s1):166184. doi:10.1111/j.1467-8330.2009.00721.x.

[11] CCT programs have been implemented or are being considered in Bangladesh, the Philippines, Malawi and other nations. Most interestingly, a CCT-type pilot program was implemented at a local level by the New York City government during the mid-00s, called Opportunity NYC, but has since folded.

[12] Lavinas L. 21st century welfare. New Left Review. 2013;(84). Available from: https://newleftreview.org/II/84/lena-lavinas-21st-centurywelfare.

[13] Molyneux M. Mothers at the service of the new poverty agenda: progresa/oportunidades, Mexico's conditional transfer programme. Social Policy \& Administration. 2006;40(4):425-449. doi:10.1111/j.14679515.2006.00497.x

[14] Barrientos A, Møller V, Saboia J, Lloyd-Sherlock P, Mase J. 'Growing'social protection in developing countries: lessons from Brazil and South Africa. Development Southern Africa. 2013;30(1):54-68. doi:10.1080/0376835X.2013.756098.

[15] Lemke T. 'The birth of bio-politics': Michel Foucault's lecture at the Collège de France on neo-liberal governmentality. Economy and Society. 2001;30(2):190-207. doi:10.1080/03085140120042271.

[16] Included herein would also be protests against GMO crops, and the question of their relationship to farmer suicides in India. Unfortunately, this is too broad a topic to be discussed here, but it does neverthe- less form an important part to the political context in which the "food security" debate has been articulated.

[17] Hertel S. Hungry for justice: Social mobilization on the right to food in India. Development and Change. 2015;46(1):72-94. doi:10.1111/dech.12144.

[18] Li TM. To make live or let die? Rural dispossession and the protection of surplus populations. Antipode. 2010;41(s1):66-93. doi:10.1111/j.1467-8330.2009.00717.x.

[19] Nair R. Public intervention for food security: the case of Kerala. Journal of Social and Economic Development. 2010;12(1):43-71.

[20] Mosse D. A relational approach to durable poverty, inequality and power. The Journal of Development Studies. 2010;46(7):1156-1178. doi:10.1080/00220388.2010.487095.

[21] Esping-Andersen G. Power and distributional regimes. Politics \& Society. 1985;14(2):223-256. doi:10.1177/003232928501400204.

[22] Sandhu A. National Food Security Act, 2013 and Food Security Outcomes in India. Vision. 2014;18(4):365-370. doi:10.1177/0972262914552174.

[23] Tanksale A, Jha J. Implementing national food security act in India: issues and challenges. British Food Journal. 2015;117(4):1315-1335. doi:10.1108/BFJ-07-2014-0239.

[24] Martinez-Alier J, Temper L, Del Bene D, Scheidel A. Is there a global environmental justice movement? The Journal of Peasant Studies. 2016;43(3):731-755. doi:10.1080/03066150.2016.1141198.

[25] Pradhan K. Fiscal Sustainability of India's National Food Security Act 2013. Margin: The Journal of Applied Economic Research. 2015;9(2):133-156. doi:10.1177/0973801014568144.

[26] Rao VS. India's food bill will not provide the security it claims. British Medical Journal. 2012;344. doi:10.1136/bmj.e3194.

[27] Bajpai V, Saraya A, et al. Food security bill and the failings of the debate around it. Indian Journal of Public Health. 2011;55(4):289.

[28] Hall A. From Fome Zero to Bolsa Família: social policies and poverty alleviation under Lula. Journal of Latin American Studies. 2006;38(4):689-709. doi:10.1017/S0022216X0600157X.

[29] Uchimura KY, Bosi MLM, Lima FELd, Dobrykopf VF. Quality of food: perceptions of'Bolsa Familia'program participants. Ciencia \& Saude Coletiva. 2012;17(3):687-694. doi:10.1590/S141381232012000300015.

[30] de Bem Lignani J, Sichieri R, Burlandy L, Salles-Costa R. Changes in food consumption among the Programa Bolsa Família participant families in Brazil. Public Health Nutrition. 2011;14(5):785-792. doi::10.1017/S136898001000279X.

[31] Martins APB, Monteiro CA. Impact of the Bolsa Família program on food availability of low-income Brazilian families: a quasi experimental study. BMC Public Health. 2016;16(1):827. doi:10.1186/s12889-0163486-y.

[32] Monteiro F, Schmidt ST, Costa IBd, Almeida CCB, Matuda NdS. Bolsa Família: food and nutrition insecurity of children under five years of age. Ciencia \& Saude Coletiva. 2014;19(5):1347-1358. doi:10.1590/1413-81232014195.21462013.

[33] Wolf MR, Barros Filho AdA. Nutritional status of beneficiaries of the" Bolsa Família" Program in Brazil-A systematic review. Ciencia \& saude coletiva. 2014;19(5):1331-1338. doi:10.1590/141381232014195.05052013. 